\title{
Study of Affordances of iPads and Teachers' Private Theories
}

\author{
Daniel Churchill, Bob Fox, and Mark King
}

\begin{abstract}
Post-PC TouchPad mobile devices are increasingly being used in educational contexts. Growing investment is planned by higher education institutions in Hong Kong and by the HKSAR Education Bureau in relation to educational uses of TouchPad technology. However, current research into educational applications of this technology is limited. This paper reports an ongoing qualitative study that investigates how higher education teachers use iPad technology to facilitate their practice. The emergent study results provide insight into both the educational affordances of iPad technology and the ways in which teachers' personal or private theories mediate these affordances and transform through the process. The study outcomes will contribute to theoretical understanding of higher education teacher changes through adoption of technology. Furthermore, the outcomes will provide a set of recommendations for applications of TouchPad technology in higher education and ways to support teachers to effectively adopt such technology in their practices.
\end{abstract}

Index Terms-Mobile Learning, Ipad, Affordances, Teacher Private Theories

\section{INTRODUCTION}

New forms of TouchPad devices have recently emerged, along with an increase in consumer demand for this technology and related software, services and content. Murphy (2011) refers to this technology as 'Post-PC' devices. Most notable among these devices is Apple's iPad, officially launched in Hong Kong in July 2010. In the next few years, it is expected that global sales of iPads will reach 395 million (Telecomasia, 2010). Nine out of 10 TouchPad devices sold globally last year were iPads (Herald Sun, 2011). Hong Kong is leading the adoption of iPads in the World. According to recent press coverage, $17 \%$ of Hong Kong people already own an iPad, a rate six times higher than the global average (Herald Sun, 2011). In addition to Apple, other major hardware designers and manufactures are delivering TouchPad devices, e.g., the Dell Streak, Samsung Galaxy Tab, ASUS EEE Pad, Blackberry Play Pad, Lenovo LePad, Cisco Cius and HP Slate.

\section{Mobile TeChnology And EducAtion}

Although Murphy (2011) refers to TouchPads as 'Post-PC' devices, this technology actually builds upon small computing technologies such as handheld portable digital assistants (PDAs). Most modern PDAs are equipped with computing capabilities, and include wireless network

Manuscript received March 13, 2012; revised April 27, 2012.

D. Churchill, B. Fox, and M. King are with Faculty of Education, The University of Hong Kong connectivity, a mobile phone, a camera as well as a variety of add-on hardware extensions. Csete, Wong and Vogel (2004) refer to this convergence as "the newest technological revolution", while Attewell (2005) suggests that as the number of devices increases globally, mobile technology will become the "digital life" for many people. TouchPad devices can overcome the key limitations of PDAs and smart phones, which have been identified in the education literature as (1) small screen real-estate with (2) limited interactivity (see Churchill, Kennedy, Flint \& Cotton, 2010; Churchill \& Hedberg, 2008; Song \& Fox, 2008; Jones, Buchanan, \& Thimbleby, 2003; Luchini, Quintana \& Soloway, 2004).

The literature suggests that PDAs might assist students to learn in many ways (see Attewell, 2005; Churchill, Kennedy, Flint \& Cotton, 2010; Clyde, 2004; Ray, 2002; Ratto, Shapiro, Truong \& Griswold, 2003; Sharples, 2000; Sharples, Corlett $\&$ Westmancott, 2002). The literature appears to suggest that mobile technology frequently receives positive feedback from students. However, Chu, Hwang, Tsai and Tseng (2010) note that although students might feel motivated when using mobile technology, their learning achievement could still be unsatisfactory. For Brand and Kinash (2010) although most existing studies explore students' perception and acceptance of mobile technology, its effect on learning is significantly under-researched. They assert that student perceptions, as well as critical and creative thinking might increase over time as a consequence of engagement with mobile learning. For Hsieh, Jang, Hwang and Chen (2011) mobile technology has the potential to support student reflection, ostensibly leading to improved learning achievement given the appropriate match between a teacher's teaching style and students' learning style. Research on teachers' uses of mobile technology to assist their teaching should provide ideas regarding the affordances of such technology in achieving learning outcomes. iPads have the potential to might become a "transformative technology" that create flexible, collaborative, and inquiry-oriented learning environments. However, we argue that appropriate models for their use must be developed.

\section{A. Educational Affordances of PDA Technology}

Given that TouchPad technologies overcome the key limitations outlined above, we argue that the expansion of use of devices like the iPad will prove to be a powerful tool in education. The extent to which TouchPads will be used in higher education depends largely on teachers' understandings of the affordances of this technology. Norman (1988) defines affordances as "the perceived and actual properties of the thing, primarily those fundamental properties that determine just how the thing could possibly be used" (p.9). Affordance is a useful concept that can be 
applied to interpret how teachers engage with technology in their practice(s), including actual uses as well as uses that emerge in practice.

Barnes (2000) argued that a teacher's use of new technology in teaching and learning is carried out with a belief that this technology will afford learning in some way. In this same vein, Klopfer and Squire (2005) describe five potential educational affordances of PDAs, including (1) portability - handhelds can be taken to different locations; (2) social interactivity - handhelds can be used to collaborate with other people; (3) context sensitivity - handhelds can be used to gather real or simulated data; (4) connectivity handhelds enable connection to data collection devices, other handhelds, and to a network; and (5) individuality handhelds can provide scaffolding for learners. Taking a different perspective, Patten, Sánches and Tangney (2006) present a framework of the affordances of PDA technology: administration, referential, interactive, microworld, data collection, location awareness, collaboration. From an educational perspective, Liaw, Hatala and Huang (2010) suggest five affordances of mobile technology: (a) educational content and knowledge delivery, (b) adaptive learning applications, (c) interactive applications, (d) individual applications, and (e) collaborative applications. Expanding upon these studies through an examination of teacher's use of PDA technology, Churchill and Churchill (2008) articulated a number of affordances of PDA technology, including as a multimedia access, connectivity, capture, representational and analytical tool. A summary of these studies is presented in Table 1. These affordances found in the literature are sorted through our analysis into emerging groups that include: (a) resources tool, (b) connectivity tool, (c) collaborative tool, (d) capture tool, (e) analytic tool, (f) representational tool, and (g) administration tool. These groups are used as an analytical framework for understanding affordances that emerge in this study.

\section{B. iPads in Education}

Although studies have provided useful ideas about the affordances of PDA technology for education, there is growing need for a more applicable framework to provide teachers, educational policy-makers and researchers with a better representation of the affordances of emerging TouchPad technologies. Current studies involving iPads in education provide useful, but limited suggestions. For example, the Catholic Education-Dioces of Paramatta in Australia experimented with iPads in eight primary and three secondary schools (Catholic Education-Dioces of Paramatta, 2010) and found that iPads were effective as: (a) support for learning in various settings due to portability and fit-for-task suitability, (b) support for student engagement and quick access to apps that students require for a particular learning task, and (c) students of all levels can use apps, especially for reinforcement and rote learning of basic concepts.

The 'Step Forward' pilot implementation of iPads at the Trinity College of the University of Melbourne suggests that this technology supports different learning styles and allows students to more quickly achieve their goals (Jennings, Anderson, Dorset \& Mitchell, 2011). Further, it is suggested that iPads are more effective that other computing technology such as laptops, and using this technology resulted in reduced printing and paper use. A survey of student and teacher experiences at the Trinity College indicates that iPads are overwhelmingly recommended for use $(76.2 \%$ of staff and $80 \%$ of students). For Jennings, Anderson, Dorset and Mitchell (2011), the advantages of iPads include educational flexibility and value, low cost, size and weight, battery life, low maintenance need, and touch screen. Murphy and Williams (2011) suggest that iPads are an effective technology for presentation of class materials via multimedia systems. The other advantages of iPads suggested in the literature include size, battery life, instant on, transition between applications, multi-touch screen, cost, e-reader, multimedia support and playback, and connection to multimedia systems. Ostashewski and Reid (2010) add that the key advantage of the iPad is that it can be used as a multimedia database. Other advantages include ease of interaction via the touch screen, screen size, controllable multimedia playback, sound volume, and data collection capabilities.

In a 2011 study at the University of San Francisco and monitored by the university's Center for Instruction and Technology, forty teachers from a number of faculties used iPads over a six month period (Bansavich, 2011). It was noted following implementation that the key advantages of iPads in higher education include the e-reader and electronic textbook capabilities, annotating and note taking for meetings and classroom features, multimedia viewing, interactivity, portability, design, ease of use, access to Apps, and speed of the device. Further research by Bansavich (2011) indicates that iPads have also been found to be effective in language learning, clinical settings, and sciences (especially due to Apps). Additionally, iPads were found to be beneficial in contexts of student advising, lab setting, fieldwork, research and tutorial viewing. A similar pilot implementation of iPads at the University of Texas at Tyler suggests that this technology promotes greater communication between students and teachers (see Beebe, 2011). Beebe (2011) infers that participating students appeared to be more motivated to attend class and turn in their assignments, and that iPads lead students to be more responsible for their learning. In addition, it was noted that students saved considerably by using e-books rather than purchasing physical books from the bookshop.

Although iPads incorporate many of the functions of a laptop and a PDA device, it is essentially a new platform for classroom computing (Walters, 2011). For Walters (2011) the key advantage of the iPad is that it is not only a consumption tool but is also beneficial for creation of ideas and content. Specifically for teachers, Walters (2011) suggests that iPads can be used as "book in their pedagogical library" and a tool that allows easy experimentation with technology. Also, teachers can easily collect assignments. Walters (2011) suggests that portability and kinesthetic interaction support students to develop visual and spatial skills, and achieve the level of "Create" at the peak of the Bloom's taxonomy. A summary of the applications of iPads in education is presented in Table II. 
TABLEII: SUMMARY OF POSITIVE CHARACTERISTICS AND EDUCTIONNAL USES Of IPAD DEVICES From LiTERATURE (BANSAVICH, 2011; BEEBE, 2011; CATHOLIC EDUCTION-DiOCES OF PARAMATTA, 2010; JENNINGS ANDERSON, DORSET \& MITCHELL,2011;MURPHY \& WILLIAMS,2011; OSTASHEWSKI\& WALTERS, 2011.

\begin{tabular}{|c|c|}
\hline Positive characteristics of iPads & Educational uses of $i$ Pads \\
\hline 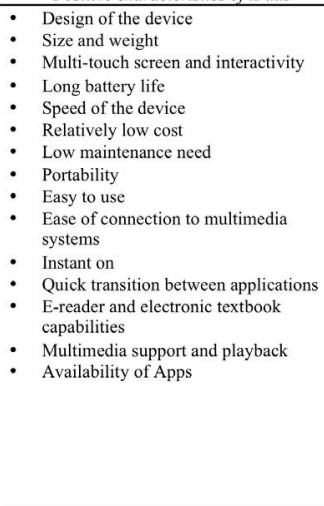 & 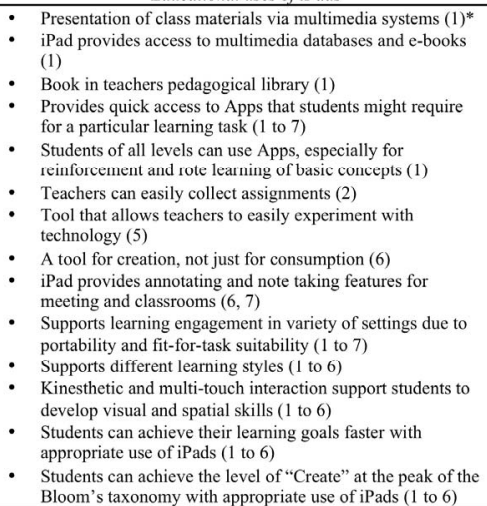 \\
\hline
\end{tabular}

\section{TEACHERS' PRIVATE THEORIES}

One of the limitations of studies on the affordances of mobile technology is that they are investigated seperate from teachers' private theories that mediate adoption of this technology. Previous studies (e.g., Churchill, 2005) indicate that teachers' use of technology is guided by a set of private theories. Previously, we conducted a study to investigate teachers' private theories and their instructional technology use (see Churchill, 2005). Six areas of teachers' private theories were identified to inform teachers' technology use.

\section{The Study of Adoption of IPAds IN TEAching IN Higher EDUCATION IN HONG KONG}

The ongoing study is being conducted for 18 -months with participants from different faculties at the University. A group of exemplary technology-using teachers representing a range of disciplines from science, humanities and art are participating. A sample of up to ten cases is sufficiently large for a qualitative case study (see Savolainen, 1994; Small, 2009; Williams, 2000). Consistency technique is used across cases to allow later comparability. The technique will also allow for the understanding of individual uniqueness given that participants derive from a range of disciplines. This understanding will contribute to the articulation of specific recommendations for the support of teachers in transforming their theories about the effective utilization of the affordances of iPad technologies. Cross-case analysis is expected to reveal areas of teachers' private theories that dominate levels of adoption of this technology. Changes in private theories through the use of iPads/Apps will reveal patterns of teacher change through such experiences, and contribute to the articulation of a model for the effective support of teachers and application of TouchPad technology in higher education.

The current stage of the study reveals interesting patterns. In the current stage, we focus on Apps downloaded and used by teachers and areas of related private theories. The Apps downloaded and used by cases are classified into the following emergent categories:

- Productivity Tools - These include tools such as word-processing, document annotation, creating of multimedia material tools. Specific Apps used include Mail, iAnnotate, Docs2PDF, Neu.Annotate, PDF Notes, Office2DH, iMovie and Dragon.

- Teaching Tools - These include tools that support classroom teaching, such as those that support connection to a projector, mark-book, presentation tools and classroom management tools. Example of Apps used are Moodle, Clicker School, TeacherPal, Prezi Viewer, Slides Shark, LanSchool Teacher.

- Notes Tools - These are tools that enable note taking in combination with audio recording, drawing and typing. Example of Apps are HansOn, Bamboo Paper, Penultimate, AudioNote, Draw Free and iPocketDraw.

- Communication Tools - These include tools that support communication and social networking. Some specific Apps include Facebook, Skype, Messages, FaceTime and MyPad.

- Drives - These include tools that allow connectivity to the Cloud, network drives and a computer. Some specific Apps include Air Shawing, FileBrowser, Dropbox, ZumoDrive, Air Drive and AirDisk.

- Blogging Tools - These tools allow convenient blogging via the iPad device. These Apps include Blogsy and Wordpress.

- Content Accessing Tools - These include tools such as e-books, multimedia material and video accessing tools. Some specific Apps include iBooks, Kindle, YouTube, Perfect Reader, iTunes and iTunesU.

Further analysis reveals an interesting pattern and connections between the affordances of iPads identified thus far and private theories of the cases, with affordances identified from previous studies on mobile technology in education (see Table I).

TABLE I: EMCRING AREAS OF THE AFFORDANCES OF IPADS AND CONNCCTIONS To PRIVATE THEORIES AND AFFORDANCES From PREVIOUS STUDIES ON MOBILE TECHNOLOGY IN EDUCATION

\begin{tabular}{|c|c|c|}
\hline 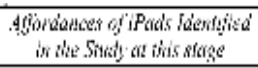 & 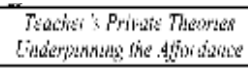 & 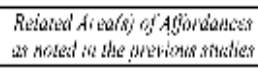 \\
\hline \multirow[t]{2}{*}{ Productlitty Tmols } & Design: & Rcseurses tobl \\
\hline & Teact:si & $\begin{array}{l}\text { Remescontational tool } \\
\text { Conmectivity tool } \\
\text { Canture tool }\end{array}$ \\
\hline \multirow[t]{2}{*}{ Teaching Tools } & Teack:s" & Resoursces tool \\
\hline & Lcarring & Adninistration tool \\
\hline \multirow[t]{2}{*}{ Vintes Tnels } & Design: & Remescontational tool \\
\hline & Teackis & Rcsoursces thol \\
\hline \multirow[t]{2}{*}{ Commuusentinu Tnenls } & Saxiznts & Connectivisy tool \\
\hline & Technolongy & Collaborative tool \\
\hline \multirow[t]{2}{*}{ Dritres } & Tcact:si & Connectivity tool \\
\hline & Technolong & Rcroursc tool \\
\hline \multirow[t]{2}{*}{ Blogging Tools } & Lcarting & Connectivity tool \\
\hline & $\begin{array}{l}\text { Sucisint } \\
\text { Tcelmolons }\end{array}$ & $\begin{array}{l}\text { Ressescntational tool } \\
\text { Collaboratire tool }\end{array}$ \\
\hline \multirow[t]{2}{*}{ Content Accessing Tools } & Su:Lint & Resource thol \\
\hline & Design. & Analytical tool \\
\hline
\end{tabular}

The emerging evidence suggests interesting possibilities for planning for interventions to support teacher's adoption of iPad technologies. The intervention ought to focus on the affordances identified in the study and expose pathways to best engage these affordances in teaching and learning, while remaining attentive to related areas of private theories that 
might facilitate or impede effective uses. A further effort is expected to reveal more detail and create conditions to improve understating of theoretical aspects of teacher changes through adoption of iPad technologies.

\section{REFERENCES}

[1] J. Attewell, Mobile technologies for learning, London, UK: Learning and Skills Development Agency, 2005.

[2] J. C. Bansavich, iPad study at USF. Retrieved September 5, 2011 from http://ipad.wiki.usfca.edu/file/view/iPad+Study+at+USF+Report.pdf.

[3] S. Barnes, What does electronic conferencing afford distance education? Distance Education, vol. 21, no. 2, 236-247, 2011.

[4] A. Beebe, iPads in the college composition classroom: A pilot program at the University of Texas at Tyler. Retrieved August 20, 2011 from http://conferences.cluteonline.com/index.php/IAC/2011NO/paper/vie $\mathrm{w} / 177,2011$.

[5] H. Borko and R. J. Shavelson, Teacher decision making. In B. F. Joney $\&$ L. Idol (Eds.), Dimensions of thinking and cognitive instructions. (pp. 311-346). Hillside, New Jersey: Lawrence Erlbaum Associates, 1990.

[6] J. Brand and S. Kinash, (2010). Pad-agogy: A quasi-experimental and ethnographic pilot test of the iPad in a blended mobile learning environment. Retrieved August 30, 2011 from http://www.ascilite.org.au/conferences/sydney10/procs/Brand-concise .pdf

[7] Catholic Education-Dioces of Paramatta. (2010). iPad in schools: Use testing. Retrieved September 5, 2011 from http://learningwithipads.blogspot.com/2011_04_01_archive.html.

[8] H. C. Chu, G. J.Hwang, C. C. Tsai, and C. R.Tseng, "A two-tier test approach to developing location-aware mobile learning systems for natural science courses," Computers and Education, vol. 55, no. 4, 1618-1627, 2010.

[9] D. Churchill, "Teachers' private theories and their design of technology-based learning," British Journal of Educational Technology, vol. 37, no. 4, 559-576, 2005.

[10] D. Churchill, and N. Churchill, "Educational affordances of PDAs: a study of a teacher's exploration of this technology," Computers and Education, vol. 50, no. 4, 1439-1450, 2008

[11] D. Churchill and G. Hedberg, "Learning object design considerations for small-screen handheld devices," Computers and Education, vol. 50, no. 3, 881-893, 2008.

[12] D. Churchill, D. M. Kennedy, D. Flint, and N. Cotton, "Using handhelds to support students' outdoor educational activities," International Journal of Continuing Engineering Education and Life-Long Learning, vol. 20, no. 1, 54-72, 2010.

[13] L. A. Clyde, M-learning. Teacher Librarian, vol. 32, no. 1, 45-46, 2004.

[14] W. J. Creswell, Qualitative inquiry and research design: choosing among five traditions. Thousand Oaks, CA: Sage Publications, 1998.

[15] J. Csete, Y. Wong, and D. Vogel, Mobile devices in and out of the classroom, World Conference on Educational Multimedia, Hypermedia and Telecommunications, pp. 4729-4736. Retrieved March 15, 2005 from http://dl.aace.org/16147, 2004.

[16] D .C. Dwyer, C. Ringstaff, and J. H. Sandholtz, (1985-1998). Apple Classroom of Tomorrow. Cupertino, CA: Apple Computer Inc. Retrieved August 30, 2001 from http://www.apple.com/education/k12/leadership/acot/library.html.

[17] B. Flyvbjerg, "Five Misunderstandings about case-study research," Qualitative Inquiry, vol. 12, no. 2, 219-245, 2006.

[18] S. W. Hsieh, Y. R. Jang, G. J. Hwang, and N. S. Chen, "Effects of teaching and learning styles on students' reflection levels for ubiquitous learning," Computers and Education, vol. 57, no. 1, 1194-1201, 2011.

[19] V. J. Janesick, "The choreography of qualitative research design. In N.K. Denzin \& Y.S. Lincoln (Eds)," Handbook of qualitative research, pp. 379-399, Thousand Oaks, CA: Sage Publications, 2000.

[20] G . Jennings, T. nderson, M. Dorset, and J. Mitchell, Report on the step forward iPad pilot project, Retrieved August 22, 2011 from http://bit.ly/lddBoy

[21] M. Jones, G. Buchanan, and H. Thimbleby, Improving web search on small screen devices. Interacting with Computers, pp. 479-495, 2003.

[22] K. E. Kendall, Continually emerging technologies: will the iPad really change the way we live and work? Decision Line,vol. 21. no. 4, pp. $11-13,2010$
[23] S. Y. Lincoln, and G. E. Guba, Naturalistic inquiry. Beverley Hills, CA.: Sage Publications, 1985.

[24] T. J. Lovat and L. D.Smith, Curriculum: action on reflection. Wentworth Falls, NSW: Social Science Press, 1990.

[25] B. S. Merriam, Case study research in education, San Francisco: CA: Jossey-Bass, 1998 .

[26] G. D. Murphy, Post-PC devices: A summary of early iPad technology adoption in tertiary environment. e-Journal of Business Education \& Scholarship of Teaching, vol. 5, no. 1, pp. 18-32,2011.

[27] T. Murphy and C. Williams, The iPad as a class presentation platform., Retrieved August 30, 2011 from http://155.225.14.146/asee-se/proceedings/ASEE2011/Papers/FP2011 mur183 199.PDF.,2011.

[28] D. A. Norman, The psychology of everyday things, New York: Basic Books, 1988 .

[29] N. Ostashewski and D. Reid, iPod, iPhone, and now iPad: The evolution of multimedia access in a mobile teaching context. In Proceedings of World Conference on Educational Multimedia, Hypermedia and Telecommunications, pp. 2862-2864.Chesapeake, VA: AACE, 2010.

[30] B. Patten, I. A. Sánches, and B. Tangney, "Designing collaborative, constructivist and contextual applications for handheld devices," Computers and Education, pp. 294-308, 2006.

[31] E. M. Pierson, Technology integration practice as a function of pedagogical expertise. Unpublished doctoral dissertation, Arizona State University, Arizona, 1999.

[32] M. Ratto, R. B. Shapiro, T. M. Truong, and W. G. Griswold, The active class project: experiments in encouraging classroom participation. Retrieved February 22, 2005 from http://www-cse.ucsd.edu/ wgg/Abstracts/activeclass-cscl03.pdf, 2003.

[33] B. Ray, (2002). PDAs in the classroom: integration strategies for K-12 educators. International Journal of Educational Technology, 3(1). $\begin{array}{llll}\text { Retrieved November } & 3, & 2004 & \text { from }\end{array}$ http://www.ao.uiuc.edu/ijet/v3n1/ray/index.html.

[34] Retrieved June 20, 2011 from http://net.educause.edu/ir/library/pdf/HR2011.pdf.

[35] J. Savolainen, "The rationality of drawing big conclusions based on small samples," Social Forces, pp. 1217-1224, 1994.

[36] M. Schömmer, "Effects of beliefs about the nature of knowledge and comprehension," Journal of Educational Psychology, 498-504,1990.

[37] M. P. Senge, "The fifth discipline: the art and practices of the learning organization," London, UK: Century Business. 1990.

[38] M. Sharples, "The design of personal mobile technologies for lifelong learning," Computers \& Education, pp. 177-193, 2000

[39] M. Sharples, D. Corlett, and O. Westmancott, "The design and implementation of a mobile learning resource," Personal and Ubiquitous Computing, pp. 220-234, 2002.

[40] M. Small, "How many cases do I need? On science and the logic of case selection in field-based research," Ethnography, pp.5-38.

[41] Y. Song and R. Fox, "Affordances of PDAs: undergraduate student perceptions," The Journal of the Research Center for Educational Technology,vol. 4,no. 1, 19-38, 2001.

[42] R. Stake, Case studies. In N. K. Denzin \& Y. S. Lincoln (Eds.), Strategies of qualitative inquiry, pp. $134-164$, Thousand Oaks, CA: Sage, 2003.

[43] Telecomasia. (2010). iPad sales hit $2 m$ in under two months. Retrieved August 5, 2010 from http://www.telecomasia.net/content/ipad-sales-hit-2m-under-two-mon ths.

[44] E. A. Walters, ( 2011). Will the iPad revolutionize education? Retrieved September 5, 2011 from http://www.iste.org/Libraries/Leading_and_Learning_Docs/May-201 1-Point-Counterpoint.sflb.ashx.

[45] H. Sun, (2011). Tablet computer ownership is highest in Hong Kong. Retrieved September 15, 2011 from http://www.heraldsun.com.au/technology/tablets/tablet-computer-own ership-is-highest-in-hong-kong/story-fn5qlb5w-1226102678709

[46] M. Williams, Interpretivism and generalization. Sociology, vol. 34, no. 2, 209-224, 2000.

[47] R. K. Yin, Case study research: design and methods. Newbury Park, CA: Sage Publications, 1989.

[48] J. R. Yinger, A study of teacher planning: description and model of preactive decision making. East Lansing, Michigan: The Institute for Research on Teaching,1978. 